\title{
Pengaruh Takaran Biochar Sekam Padi dan Kompos Kotoran Ayam terhadap Pertumbuhan dan Hasil Kubis Bunga (Brassica Oleraceae, L.)
}

\author{
Theodorus Talo Mau ${ }^{\mathrm{a}}$, Eduardus Yosef Neonbeni ${ }^{\mathrm{b}}$ \\ ${ }^{a}$ Fakultas Pertanian, Universitas Timor, Kefamenanu, TTU - NTT, Indonesia,email: talomautheodorus@gmail.com \\ ${ }^{b}$ Fakultas Pertanian, Universitas Timor, Kefamenanu,TTU-NTT, Indonesia, email:ambeni02@gmail.com
}

\section{Article Info}

\section{Article history:}

Received 14 Januari 2019

Received in revised form 28 Februari 2019

Accepted 29 Maret 2018

DOI:

https://doi.org/10.32938/sc.v4i02.579

Keywords:

Takaran biocha

Kompos kotoran ayam

Brassica oleracea, L

\begin{abstract}
Abstrak
Kubis bunga (Brassica oleracea, L.) atau kembang kol merupakan komoditas sayur yang dikonsumsi massa bunganya (curd). Jenis sayuran ini sangat di gemari masyarakat umum selain karena cita rasanya enak dan lezat untuk di buat sop dan juga mengandung gizi yang cukup tinggi. Tujuan penelitian ini adalah untuk mengetahui pengaruh takaran biochar sekam padi dan kompos kotoran ayam terhadap pertumbuhan dan hasil kubis bunga. Penelitian ini telah dilaksanakan pada bulan Agustus sampai Oktober 2017, di kebun percobaan Fakultas Pertanian Universitas Timor, Kelurahan Sasi, Kecamatan Kota Kefamenanu, Kabupaten TTU. Rancangan yang digunakan adalah Rancangan Acak Kelompok (RAK) faktorial 3x3 yang diulang 3 kali. Faktor pertama adalah biochar sekam padi yang terdiri dari 3 aras yaitu tanpa penggunaan biochar, biochar 2,5 t/ha, biochar $5 \mathrm{t} / \mathrm{ha}$ dan faktor kedua adalah kompos kotoran ayam yang terdiri dari tiga aras yaitu tanpa kompos, kompos 2,5 t/ha, kompos $5 \mathrm{t} / \mathrm{ha}$. Hasil penelitian menunjukan bahwa tidak terjadi interaksi antar parameter baik pada parameter lingkungan maupun pada parameter hasil, namun perlakuan biochar $5 \mathrm{t} / \mathrm{ha}$ dan kompos kotoran ayam 5 $\mathrm{t} / \mathrm{ha}$ memberikan pertumbuhan tanaman kubis bunga terbaik.
\end{abstract}

\section{Pendahuluan}

Kubis bunga (Brassica oleracea, L.) atau kembang kol merupakan komoditas sayur yang dikonsumsi massa bunganya (curd), tergolong dalam famili kubis-kubisan (Cruciferae), memiliki kandungan utama senyawa tiosianat dan glukosinolat. Salah satu zat aktif anti kanker yang terkandung dalam kubis bunga adalah zat sulforafan dan indol. Zat-zat ini sangat efektif untuk mencegah pertumbuhan sel kanker payudara, prostat, ginjal, kolon, kandung kemih dan paru-paru (Sunarsih dkk., 2011). Menurut data Badan Pusa Statistik (BPS), produksi kubis bunga di Indonesia pada tahun 2011 sebesa 113,491 ton, tahun 2012 sebesar 135,837 ton, dan tahun 2013 sebesar 151,288 ton. Sedangkan pada tahun 2014 mengalami penurunan menjadi 136,514 ton (BPS, 2015). Produktivitas kubis bunga nasional adalah 12,08 t/ha, sedangkan untuk provinsi NTT 3,19 t/ha (Kementan RI, 2015). Disamping penurunan produksi, kubis bunga masih menghadapi masalah, seperti penggunaan pupuk kimia yang tinggi dan pertanaman yang lebih dominan di dataran tinggi Budidaya kubis bunga di Nusa Tengara Timur relatif masih rendah, kubis bunga banyak dibudidayakan di kabupaten TTU tetapi masih dalam skala kecil atau hanya untuk kebutuhan rumah tangga.

Hal ini disebabkan oleh lahan pertanian di daerah ini sebagian besar didominasi oleh tanah entisol yang memiliki solum tanah tipis dan miskin unsur hara. Tanah ini mempunyai kandungan $\mathrm{C}$ organik, $\mathrm{N}$ dan $\mathrm{P}$ yang rendah, serta mempunyai kandungan liat yang cukup tinggi. Sedangkan Tanaman kubis bunga lebih cocok dibudidayakan ditanah yang memiliki tekstur liat berpasir atau liat berlempung yang subur. Kemasaman $(\mathrm{pH})$ tanah berada pada kisaran 6-8 (Rubatzaky \& Yamaguchi, 1998). Salah satu upaya yang dapat dilakukan untuk memperbaiki kondisi tanah inseptisol dengan menambahkan bahan organik seperti biochar dan kompos kotoran ayam, dengan tujuan memperbaiki sifat fisik, kimia dan biologi tanah serta meningkatkan produktivitas tanaman.

Biochar merupakan bahan padatan yang terbentuk melalui proses pembakaran bahan organik tanpa oksigen (pyrolysis) pada temperatur 250$500^{\circ} \mathrm{C}$. Biochar mampu mensekuestrasi karbon dalam tanah dan telah terbukt bertahan dalam tanah hingga $>1000$ (Lehmann, 2007). Beberapa penelitian mengungkapkan bahwa biochar sekam padi mampu memperbaiki tanah dan meningkatkan produktivitas tanaman. Peran biochar sekam dalam memperbaik kesuburan tanah diantaranya adalah dengan mengefektifkan pemupukan, dimana biochar dapat mengikat hara (pada saat kelebihan hara) dan dapa dilepaskan pada saat tanaman membutuhkan (slow release), sehingga tanaman terhindar dari keracunan hara (terutama hara mikro) dan kekurangan hara Kelebihan biochar dibandingkan bahan organik lainnya adalah lebih persisten dalam tanah, sehingga semua manfaat yang berhubungan dengan perbaikan kesuburan tanah dapat berjalan lebih lama, sementara pupuk organik mengalami pembusukan yang mengemisikan gas berupa metana, yang meningkatkan pemanasan global (Gani, 2009). Selain itu berperan dalam memperbaiki sifat-sifat fisik tanah (Sun dan Lu, 2014) serta sifat-sifat kimia tanah diantaranya ketersediaan beberapa unsur hara tanah (Kloss dkk., 2014). Disamping penggunaan biochar, pemupukan juga perlu diperhatikan seperti pemupukan secara organik mampu berperan memobilisasi atau menjembatani hara yang sudah ada di tanah sehingga mampu membentuk partikel ion yang mudah diserap oleh akar tanaman (Simalango, 2009).

Menurut Ardi dan Simanungkalit (2006), pupuk organik adalah bahan organik yang telah melalui proses rekayasa dengan bahan dasar dari tanaman dan atau hewan, dapat berbentuk padat atau cair dengantujuan memperbaiki sifat fisik, kimia, dan biologi tanah. Salah satu pupuk organik adalah pupuk kandang yang merupakan produk buangan dari binatang peliharaan sepert ayam, kambing, sapi dan kerbau yang dapat digunakan untuk menambah hara, memperbaiki sifat fisik dan biologi tanah. Kualitas pupuk kandang sanga berpengaruh terhadap respon tanaman. Pupuk kandang ayam secara umum mempunyai kelebihan dalam kecepatan penyerapan hara oleh tanaman lebih cepat, komposisi hara seperti $\mathrm{N}, \mathrm{P}, \mathrm{K}$ dan $\mathrm{Ca}$ lebih tinggi dibandingkan pupuk kandang sapi dan kambing (Widowati, 2004). Berdasarkan uraian tersebu maka penelitian ini bertujuan untuk mendapatkan takaran biochar sekam padi dan takaran kompos kotoran ayam terbaik terhadap pertumbuhan dan hasil kubis bunga.

\section{Metode}

Penelitian ini telah dilaksanakan pada bulan Agustus sampai Oktober 2017, di kebun percobaan Fakultas Pertanian Universitas Timor, Kelurahan Sasi, Kecamatan Kota Kefamenanu, Kabupaten TTU. Rancangan yang digunakan dalam penelitian ini yaitu Rancangan Acak Kelompok (RAK) faktorial $3 \times 3$ yang diulang 3 kali. Faktor pertama adalah biochar sekam padi (B) yang terdiri dari 3 aras yaitu tanpa penggunaan biochar $\left(\mathrm{B}_{0}\right)$, biochar 2,5 $\mathrm{t} / \mathrm{ha}\left(\mathrm{B}_{1}\right)$, biochar $5 \mathrm{t} / \mathrm{ha}\left(\mathrm{B}_{2}\right)$ dan faktor kedua adalah kompos kotoran ayam $(\mathrm{K})$ yang terdiri dari tiga aras yaitu tanpa kompos $\left(\mathrm{K}_{0}\right)$, kompos $2,5 \mathrm{t} / \mathrm{ha}\left(\mathrm{K}_{1}\right)$, kompos 5 t/ha $\left(\mathrm{K}_{2}\right)$, dengan kombinasi perlakuan: $\mathrm{B}_{0} \mathrm{~K}_{0}, \mathrm{~B}_{0} \mathrm{~K}_{1}, \mathrm{~B}_{0} \mathrm{~K}_{2}$, $\mathrm{B}_{1} \mathrm{~K}_{0}, \mathrm{~B}_{1} \mathrm{~K}_{1}, \mathrm{~B}_{1} \mathrm{~K}_{2}, \mathrm{~B}_{2} \mathrm{~K}_{0}, \mathrm{~B}_{2} \mathrm{~K}_{1}, \mathrm{~B}_{2} \mathrm{~K}_{2}$, sehingga terdapat 27 unit percobaan. Pelaksanaan penelitian diawali dengan membersihkan lahan dari gulma dan vegetasi lainnya untuk selanjutnya dilakukan pengolahan. Pengolahan tanah dilakukan dengan menggunakan cangkul dan linggis dengan mengikuti garis kontur yang telah di tentukan menggunakan bingkai A. Setelah itu dilanjutkan dengan pembuatan bedeng dengan ukuran $140 \mathrm{~cm}$ x $180 \mathrm{~cm}$. Setelah lahan disiapkan dilanjutkan dengan pembenaman kompos dan biochar sesuai dengan perlakuan yaitu takaran $0 \mathrm{t} / \mathrm{ha}, 2,5 \mathrm{t} / \mathrm{ha}$ dan $5 \mathrm{t} / \mathrm{ha}$.

Selanjutnya kompos dan biochar diinkubasi selama 21 hari dan dilakukan penyiraman sekali sehari agar kelembaban kompos dan biochar terus terjaga serta kompos dan biochar bersatu dengan tanah olahan. Setelah masa inkubasi selesai dilanjutkan dengan penanaman pada saat bibit yang telah disiapkan berumur 28 hari setelah semai dengan jarak tanam $30 \mathrm{~cm} \times 40 \mathrm{~cm}$ pada sore hari untuk menghindari pengaruh matahari dan temperature tinggi, kemudian disiram sampai basah. Dalam penelitian diperlukan pemeliharan pada tanaman berupa penyiraman, penyulaman, penyiangan dan penggemburan tanah, pengendalian hama dan penyakit. Panen dilakukan pada saat tanaman berumur 70 HST yang mana pada umur ini ukuran bunga telah mencapai maksimal. Variabel pengamatan dalam penelitian ini berupa:

1. Tinggi tanaman $(\mathrm{cm})$

Tinggi tanaman diukur dari pangkal batang hingga pucuk yang paling tinggi dengan menggunakan mistar. Pengukuran dilakukan pada tiga sampel tanaman setiap bedeng saat berumur 21, 28, 35 dan 42 HST.

2. Diameter batang $(\mathrm{cm})$

Pengukuran diameter batang dilakukan pada saat tanaman berumur 21, 28, 35 dan 42 HST menggunakan jangka sorong pada pangkal batang $\pm 2 \mathrm{~cm}$ dari permukaan tanah. Pengukuran diameter batang dilakukan pada 3 tanaman sampel.

3. Jumlah daun (helai)

Jumlah daun dihitung pada setiap sampel tanaman. Jumlah daun diukur pada saat tanaman berumur 21, 28, 35 dan 42 HST pada 3 tanaman sampel.

4. Luas daun $\left(\mathrm{cm}^{2}\right)$

Luas daun diukur pada saat akhir penelitian atau setelah panen Pengukuran luas daun menggunakan metode fotometri dengan cara mengambil semua daun pada 3 tanaman sampel dari setiap kombinasi perlakuan, kemudian discan, setelah itu luas daun dihitung menggunakan program image $J$ versi 1.40

5. Diameter bunga $(\mathrm{cm})$

Bunga kubis yang telah dipanen pada setiap sampel diukur diameternya menggunakan jangka sorong.

6. Bobotbunga per tanaman (g)

Bunga kubis yang telah dipanen dari tanaman sampel dipisahkan dari daun, batang dan akar, kemudian ditimbang menggunakan timbangan analitik dan dirata-ratakan.

7. Bobot bunga per petak ( $t / \mathrm{ha})$

Bunga kubis yang telah dipanen dari setiap petak ditimbang menggunakan timbangan analitik kemudian dikonversikan kedalam satuan ton. 
Data hasil pengamatan yang telah dikumpulkan dari penelitian dianalisis menggunakan analisa sidikragam (Anova) dengan Rancangan Acak Kelompok (RAK) faktorial. Rata-rata perlakuan selanjutnya diuji lanjut dengan menggunakan Duncan Multiple Range Test (DMRT) dengan tingkat signifikan 0.05 sesuai petunjuk Gomez dan Gomez (1995). Analisa data menggunakan program SAS 9.1.

\section{Hasil dan Pembahasan \\ 3.1 Hasil}

\section{Tinggi Tanaman}

Hasil analisis sidik ragam (Anova) menunjukkan bahwa kombinasi perlakuan takaran biochar sekam padi dan kompos kotoran ayam tidak terjadi interaksi terhadap parameter pengamatan tinggi tanaman pada seluruh waktu pengamatan. Hasil uji lanjut DMRT menunjukkan takaran biochar tidak berbeda nyata tetapi takaran biochar 5 t/ha menghasilkan tinggi tanaman tertinggi pada waktu pengamatan 42 HST sedangkan takaran kompos kotoran ayam berbeda nyata pada pengamatan 28 HST, 35 HST dan 42 HST yang mana takaran kompos kotoran ayam $5 \mathrm{t} / \mathrm{ha}$ menghasilkan tinggi tanaman paling tingg yang berbeda nyata dengan kontrol pada waktu pengamatan 42 HST, tetapi pada umur 21 HST tidak berbeda nyata.

\section{Tabel 1. Pengaruh perlakuan terhadap tinggi tanaman $(\mathrm{cm})$}

\begin{tabular}{cccccc}
\hline \multirow{2}{*}{$\begin{array}{c}\text { Waktu } \\
\text { Pengamatan }\end{array} \begin{array}{c}\text { Takaran } \\
\text { Kompos }\end{array}$} & \multicolumn{4}{c}{ Takaran Biochar (t/ha) } & \multirow{2}{*}{ Rerata } \\
\cline { 3 - 5 } & $\begin{array}{c}\text { Kotoran Ayam } \\
\text { (t/ha) }\end{array}$ & 0 & 2,5 & 5 & \\
\hline \multirow{2}{*}{21} & 0 & 6,89 & 7,36 & 7,77 & $7,34 \mathrm{a}$ \\
& 2,5 & 9,28 & 7,83 & 11,19 & $9,43 \mathrm{a}$ \\
& 5 & 11,36 & 11,13 & 10,40 & $10,96 \mathrm{a}$ \\
\hline Rerata & & $9,18 \mathrm{a}$ & $8,77 \mathrm{a}$ & $9,79 \mathrm{a}$ & $(-)$ \\
\hline \multirow{2}{*}{28} & 0 & 9,02 & 10,66 & 12,13 & $10,60 \mathrm{c}$ \\
& 2,5 & 17,19 & 13,95 & 19,64 & $16,93 \mathrm{~b}$ \\
& 5 & 20,45 & 20,08 & 19,15 & $19,89 \mathrm{a}$ \\
\hline Rerata & & $15,55 \mathrm{a}$ & $14,90 \mathrm{a}$ & $16,97 \mathrm{a}$ & $(-)$ \\
\hline \multirow{3}{*}{35} & 0 & 14,08 & 15,25 & 17,03 & $15,45 \mathrm{~b}$ \\
& 2,5 & 22,55 & 20,57 & 26,34 & $23,15 \mathrm{a}$ \\
& 5 & 27,76 & 27,15 & 26,52 & $27,14 \mathrm{a}$ \\
\hline Rerata & & $21,47 \mathrm{a}$ & $20,99 \mathrm{a}$ & $23,30 \mathrm{a}$ & $(-)$ \\
\hline \multirow{2}{*}{42} & 0 & 17,21 & 18,47 & 19,05 & $18,24 \mathrm{~b}$ \\
& 2,5 & 27,47 & 24,29 & 29,56 & $27,10 \mathrm{a}$ \\
& 5 & 31,02 & 32,84 & 29,30 & $31,07 \mathrm{a}$ \\
\hline Rerata & & $25,23 \mathrm{a}$ & $25,20 \mathrm{a}$ & $25,97 \mathrm{a}$ & $(-)$ \\
\hline
\end{tabular}

Keterangan : Angka yang diikuti huruf yang sama pada baris atau kolom yang sama tidak berbeda nyata menurut uji DMRT@5\%. (-) tidak adanya interaksi antar faktor.

\section{Diameter Batang}

Hasil analisis sidik ragam (Anova) menunjukkan bahwa kombinasi perlakuan takaran biochar sekam padi dan kompos kotoran ayam tidak terjadi interaksi terhadap parameter pengamatan diameter batang pada seluruh waktu pengamatan. Hasil uji lanjut DMRT menunjukkan bahwa takaran biochar tidak berbeda nyata, dengan perlakuan tanpa biochar menghasilkan diameter batang terbesar pada waktu pengamatan 42 HST sedangkan takaran kompos kotoran ayam berbeda nyata pada seluruh waktu pengamatan dengan takaran kompos kotoran ayam $5 \mathrm{t} / \mathrm{ha}$ menghasilkan diameter batang terbesar yang berbeda nyata dengan kontrol pada waktu pengamatan 42 HST.

Tabel 2. Pengaruh perlakuan terhadap diameter batang $(\mathrm{cm})$

\begin{tabular}{|c|c|c|c|c|c|}
\hline \multirow{2}{*}{$\begin{array}{c}\text { Waktu } \\
\text { Pengamatan } \\
\text { (HST) }\end{array}$} & \multirow{2}{*}{$\begin{array}{c}\text { Takaran Kompos } \\
\text { Kotoran Ayam } \\
(\mathrm{t} / \mathrm{ha})\end{array}$} & \multicolumn{3}{|c|}{ Takaran Biochar (t/ha) } & \multirow{2}{*}{ Rerata } \\
\hline & & 0 & 2,5 & 5 & \\
\hline \multirow{3}{*}{21} & 0 & 0,32 & 0,31 & 0,36 & $0,33 \mathrm{~b}$ \\
\hline & 2,5 & 0,42 & 0,35 & 0,44 & $0,40 \mathrm{a}$ \\
\hline & 5 & 0,52 & 0,47 & 0,42 & $0,47 \mathrm{a}$ \\
\hline Rerata & & $0,42 \mathrm{a}$ & $0,38 \mathrm{a}$ & $0,40 \mathrm{a}$ & $(-)$ \\
\hline \multirow{3}{*}{28} & 0 & 0,33 & 0,35 & 0,39 & $0,35 \mathrm{c}$ \\
\hline & 2,5 & 0,50 & 0,40 & 0,61 & $0,50 \mathrm{~b}$ \\
\hline & 5 & 0,69 & 0,63 & 0,52 & $0,61 \mathrm{a}$ \\
\hline Rerata & & $0,50 \mathrm{a}$ & $0,46 \mathrm{a}$ & $0,50 \mathrm{a}$ & $(-)$ \\
\hline \multirow{3}{*}{35} & 0 & 0,46 & 0,55 & 0,55 & $0,52 \mathrm{~b}$ \\
\hline & 2,5 & 0,93 & 0,70 & 1,03 & $0,88 \mathrm{a}$ \\
\hline & 5 & 0,93 & 0,95 & 0,87 & $0,92 \mathrm{a}$ \\
\hline Rerata & & $0,77 \mathrm{a}$ & $0,73 \mathrm{a}$ & $0,82 \mathrm{a}$ & $(-)$ \\
\hline \multirow{3}{*}{42} & 0 & 1,09 & 0,63 & 0,68 & $0,80 \mathrm{~b}$ \\
\hline & 2,5 & 0,99 & 0,85 & 1,15 & $1,00 \mathrm{ab}$ \\
\hline & 5 & 1,14 & 1,20 & 1,08 & $1,14 \mathrm{a}$ \\
\hline Rera & & $1,07 \mathrm{a}$ & $0,89 \mathrm{a}$ & $0,97 \mathrm{a}$ & $(-)$ \\
\hline
\end{tabular}

Keterangan: Angka yang diikuti huruf yang sama pada baris atau kolom yang sama tidak berbeda nyata menurut uji DMRT @ 5 \%. (-) tidak adanya interaksi antar faktor.

\section{Jumlah Daun}

Hasil analisis sidik ragam (Anova) menunjukkan bahwa kombinasi perlakuan takaran biochar sekam padi dan kompos kotoran ayam tidak terjadi interaksi terhadap parameter pengamatan jumlah daun pada seluruh waktu pengamatan. Hasil uji lanjut DMRT menunjukkan bahwa takaran biochar tidak berbeda nyata, tetapi perlakuan biochar $5 \mathrm{t} / \mathrm{ha}$ menghasilkan jumlah daun paling banyak pada waktu pengamatan 42 HST sedangkan takaran kompos kotoran ayam berbeda nyata pada seluruh waktu pengamatan dengan takaran kompos kotoran ayam $5 \mathrm{t} / \mathrm{ha}$ menghasilkan jumlah daun terbanyak yang berbeda nyata dengan kontrol pada waktu pengamatan 42 HST.

Tabel 3. Pengaruh perlakuan terhadap jumlah daun (Helai)

\begin{tabular}{|c|c|c|c|c|c|}
\hline \multirow{2}{*}{$\begin{array}{l}\text { Waktu } \\
\text { Pengamatan } \\
\text { (HST) }\end{array}$} & \multirow{2}{*}{$\begin{array}{c}\text { Takaran Kompos } \\
\text { Kotoran Ayam } \\
\text { (t/ha) }\end{array}$} & \multicolumn{3}{|c|}{ Takaran Biochar (t/ha) } & \multirow{2}{*}{ Rerata } \\
\hline & & 0 & 2,5 & 5 & \\
\hline \multirow{3}{*}{21} & 0 & 4,33 & 4,66 & 4,99 & $4,66 \mathrm{c}$ \\
\hline & 2,5 & 5,66 & 4,78 & 6,00 & $5,48 \mathrm{~b}$ \\
\hline & 5 & 6,66 & 6,44 & 5,55 & $6,22 \mathrm{a}$ \\
\hline Rerata & & $5,55 \mathrm{a}$ & $5,29 \mathrm{a}$ & $5,51 \mathrm{a}$ & $(-)$ \\
\hline \multirow{3}{*}{28} & 0 & 5,22 & 6,33 & 6,66 & $6,07 \mathrm{~b}$ \\
\hline & 2,5 & 7,67 & 6,89 & 8,22 & $7,59 \mathrm{a}$ \\
\hline & 5 & 8,44 & 8,66 & 7,77 & $8,29 \mathrm{a}$ \\
\hline Rerata & & $7,11 \mathrm{a}$ & $7,29 \mathrm{a}$ & $7,55 \mathrm{a}$ & $(-)$ \\
\hline \multirow{3}{*}{35} & 0 & 7,33 & 9,00 & 9,44 & $8,59 \mathrm{~b}$ \\
\hline & 2,5 & 11,00 & 9,77 & 11,67 & $10,81 \mathrm{a}$ \\
\hline & 5 & 11,22 & 11,55 & 11,11 & $11,29 \mathrm{a}$ \\
\hline Rerata & & $9,85 \mathrm{a}$ & $10,11 \mathrm{a}$ & $10,74 \mathrm{a}$ & $(-)$ \\
\hline \multirow{3}{*}{42} & 0 & 9,00 & 9,89 & 10,22 & $9,70 \mathrm{~b}$ \\
\hline & 2,5 & 13,11 & 11,89 & 13,89 & $12,96 \mathrm{a}$ \\
\hline & 5 & 13,88 & 14,11 & 13,00 & $13,66 \mathrm{a}$ \\
\hline Rerata & & $11,99 \mathrm{a}$ & $11,96 \mathrm{a}$ & $12,37 \mathrm{a}$ & $(-)$ \\
\hline
\end{tabular}

Keterangan : Angka yang diikuti huruf yang sama pada baris atau kolom yang sama tidak berbeda nyata menurut uji DMRT@5\%. (-) tidak adanya interaksi antar faktor.

\section{Luas daun}

Hasil analisis sidik ragam (Anova) menunjukkan bahwa kombinas perlakuan takaran biochar sekam padi dan kompos kotoran ayam tidak terjadi interaksi terhadap parameter pengamatan luas daun. Hasil uji lanjut DMRT menunjukkan bahwa takaran biochar tidak berbeda nyata, tetapi perlakuan biochar $5 \mathrm{t} / \mathrm{ha}$ menghasilkan daun paling luas sedangkan takaran kompos kotoran ayam berbeda nyata, dengan takaran kompos kotoran ayam 5 t/ha menghasilkan daun paling luas yang berbeda nyata dengan kontrol.

Tabel 4. Pengaruh perlakuan terhadap luas daun per tanaman $\left(\mathrm{cm}^{2}\right)$

\begin{tabular}{cccccr}
\hline \multirow{2}{*}{$\begin{array}{c}\text { Waktu } \\
\text { Pengamatan }\end{array}$} & $\begin{array}{c}\text { Takaran Kompos } \\
\text { Kotoran Ayam } \\
\text { (t/ha) }\end{array}$ & \multicolumn{3}{c}{ Takaran Biochar (t/ha) } & \multirow{2}{*}{ Rerata } \\
\cline { 3 - 5 } & 0 & 0 & 2,5 & 5 & \\
\hline \multirow{2}{*}{ Panen } & 2,5 & 134,4 & 147,9 & 160,7 & $147,7 \mathrm{~b}$ \\
& 5 & 224,0 & 196,0 & 251,8 & $224,0 \mathrm{a}$ \\
& 264,1 & 266,9 & 249,9 & $260,3 \mathrm{a}$ \\
\hline Rerata & & $207,5 \mathrm{a}$ & $203,6 \mathrm{a}$ & $220,8 \mathrm{a}$ & $(-)$ \\
\hline
\end{tabular}

Keterangan: Angka yang diikuti huruf yang sama pada baris atau kolom yang sama tidak berbeda nyata menurut uji DMRT@5\%. (-) tidak adanya interaksi antar faktor.

\section{Diameter Bunga}

Hasil analisis sidik ragam (Anova) menunjukkan bahwa kombinasi perlakuan takaran biochar sekam padi dan kompos kotoran ayam tidak terjadi interaksi terhadap parameter pengamatan diameter bunga. Hasil uji lanjut DMRT menunjukkan bahwa takaran biochar tidak berbeda nyata, tetapi perlakuan biochar $5 \mathrm{t} / \mathrm{ha}$ menghasilkan diameter bunga paling besar sedangkan takaran kompos kotoran ayam berbeda nyata, dengan takaran kompos kotoran ayam $5 \mathrm{t} / \mathrm{ha}$ menghasilkan diameter bunga paling besar yang berbeda nyata dengan kontrol.

Tabel 5. Pengaruh Perlakuan terhadap Diameter Bunga per Tanaman (mm)

\begin{tabular}{cccccc}
\hline \multirow{2}{*}{$\begin{array}{c}\text { Waktu Pengamatan } \\
(\text { HST) }\end{array}$} & $\begin{array}{c}\text { Takaran Kompos } \\
\text { Kotoran Ayam }\end{array}$ & \multicolumn{2}{c}{ Takaran Biochar (t/ha) } & \multirow{2}{*}{ Rerata } \\
\cline { 3 - 5 } & $(\mathrm{t} / \mathrm{ha})$ & 0 & 2,5 & 5 & \\
\hline \multirow{2}{*}{ Panen } & 0 & 6,93 & 6,30 & 6,77 & $6,66 \mathrm{~b}$ \\
& 2,5 & 7,90 & 8,87 & 8,38 & $7,72 \mathrm{ab}$ \\
& 5 & 8,44 & 8,04 & 8,27 & $8,25 \mathrm{a}$ \\
\hline Rerata & & $7,75 \mathrm{a}$ & $7,07 \mathrm{a}$ & $7,81 \mathrm{a}$ & $(-)$ \\
\hline
\end{tabular}

Keterangan: Angka yang diikuti huruf yang sama pada baris atau kolom yang sama tidak berbeda nyata menurut uji DMRT@5\%. (-) tidak adanya interaksi antar faktor.

\section{Berat Bunga Per Tanaman}

Hasil analisis sidik ragam (Anova) menunjukkan bahwa kombinas iperlakuan takaran biochar sekam padi dan kompos kotoran ayam tidak terjadi interaksi terhadap parameter pengamatan beratbunga per tanaman. Hasil uji lanjut DMRT menunjukkan bahwa baik takaran biochar maupun takaran kompos kotoran ayam tidak berbeda nyata. 
Tabel 6. Pengaruh perlakuan terhadap berat bunga pertanaman (g)

\begin{tabular}{|c|c|c|c|c|c|}
\hline \multirow{2}{*}{$\begin{array}{c}\text { Waktu } \\
\text { Pengamatan } \\
\text { (HST) }\end{array}$} & \multirow{2}{*}{$\begin{array}{c}\text { Takaran Kompos } \\
\text { Kotoran Ayam } \\
(\mathrm{t} / \mathrm{ha})\end{array}$} & \multicolumn{3}{|c|}{ Takaran Biochar (t/ha) } & \multirow{2}{*}{ Rerata } \\
\hline & & 0 & 2,5 & 5 & \\
\hline \multirow{3}{*}{ Panen } & 0 & 25,80 & 24,99 & 26,17 & $25,65 \mathrm{a}$ \\
\hline & 2,5 & 25,46 & 24,56 & 25,82 & $25,29 \mathrm{a}$ \\
\hline & 5 & 26,52 & 26,45 & 24,91 & $25,96 \mathrm{a}$ \\
\hline Rerata & & $25,93 \mathrm{a}$ & $25,34 \mathrm{a}$ & $25,63 \mathrm{a}$ & $(-)$ \\
\hline
\end{tabular}

Keterangan: Angka yang diikuti huruf yang sama pada baris atau kolom yang sama tidak berbeda nyata menurut uji DMRT@ @ \%. (-) tidak adanya interaksi antar faktor.

\section{Berat Bunga Per Petak}

Hasil analisis sidik ragam (Anova) menunjukkan bahwa kombinasi perlakuan takaran biochar sekam padi dan kompos kotoran ayam tidak terjadi interaksi terhadap parameter pengamatan berat bunga per petak. Hasil uji lanjut DMRT menunjukkan bahwa takaran biochar tidak berbeda nyata, dengan perlakuan tanpa biochar menghasilkan beratbunga paling tinggi sedangkan takaran kompos kotoran ayam berbeda nyata, dengan takaran kompos kotoran ayam $5 \mathrm{t} / \mathrm{ha}$ menghasilkan berat bunga paling tinggi yang berbeda nyata dengan kontrol.

Tabel 7. Pengaruh perlakuan terhadap berat bunga per petak (t/ha)

\begin{tabular}{cccccc}
\hline \multirow{2}{*}{$\begin{array}{c}\text { Waktu } \\
\text { Pengamatan } \\
\text { (HST) }\end{array}$} & $\begin{array}{c}\text { Takaran Kompos } \\
\text { Kotoran Ayam (t/ha) }\end{array}$ & \multicolumn{2}{c}{ Takaran Biochar (t/ha) } & \multirow{2}{*}{ Rerata } \\
\cline { 3 - 5 } & 0 & 0 & 2,5 & 5 & \\
\hline \multirow{2}{*}{ Panen } & 2,5 & 2.85 & 1.83 & 2.15 & $2.28 \mathrm{~b}$ \\
& 5 & 3.36 & 3.51 & 2.69 & $2.64 \mathrm{ab}$ \\
& & $2.86 \mathrm{a}$ & $2.73 \mathrm{a}$ & $2.68 \mathrm{a}$ & $(-)$
\end{tabular}

Keterangan : Angka yang diikuti huruf yang sama pada baris atau kolom yang sama tidak berbeda nyata menurut uji DMRT @ 5 \%. (-) tidak adanya interaksi antar faktor.

\subsection{Pembahasan}

Hasil penelitian menunjukkan bahwa pemberian biochar sekam padi dan kompos kotoran ayam tidak terjadi interaksi antar faktor perlakuan, namun pemberian biochar dan kompos kotoran ayam dengan takaran 5 ton/ha mempengaruhi pertumbuhan dan hasil tanaman kubis bunga hal ini dapat dibuktikan dengan peningkatan pertumbuhan kubis bunga pada pengamatan parameter tinggi tanaman, tinggi tanaman kubis bunga mengalami peningkatan pada setiap minggunya yakni pada $21 \mathrm{HST}, 28,35$, dan 42 HST. Pengaruh yang nyata dapat dilihat pada pengamatan 42 HST dimana pengamatan menunjukan tinggi tanaman kubis bunga tertinggi yaitu sebesar $(31,07 \mathrm{~cm}$ untuk pemberian kompos kotoran ayam dan 25,97 $\mathrm{cm}$ untuk pemberian biochar sekam padi). Pengaruh pemberian biochar sekam padi dan kompos kotoran ayam tidak hanya berpengaruh terhadap pengamatan tinggi tanaman saja tetapi menunjukan hubungan yang erat dengan pengamatan parameter lainya seperti diameter batang dan jumlah daun.

Diameter batang terbesar terdapat pada pengamatan 42 HST yaitu sebesar $0.97 \mathrm{~cm}$ dan $1,14 \mathrm{~cm}$ sedangkan jumlah daun terbanyak juga terdapat pada pengamatan 42 HST yakni sebesar 12,37 helai dan 13,60 helai.Selain itu pengaruh pemberian biochar sekam padi dan pemberian kompos kotoran ayam berpengaruh terhadap pengamatan luas daun yaitu sebesar $220,8 \mathrm{~cm}^{2}$ untuk pemberian biochar dan $260,3 \mathrm{~cm}^{2}$ untuk pemberian kompos kotoran ayam, hal ini dikarenakan perlakuan pupuk padat kotoran ayam (kompos) memberikan kerapatan isi tanah lebih rendah dan kandungan $\mathrm{C}$ organik yang lebih tinggi sehingga struktur tanah menjadi lebih baik dan akar tanaman akan mudah berkembang sehingga perkembangan tanaman menjadi lebih baik dan berlangsungnya proses pertambahan jumlah daun. Unsur hara nitrogen yang berasal dari kotoran ternak padat yang dimanfaatkan sebagai bahan organik, periode pertumbuhan tanaman akan diperpanjang hingga pada akhirnya setiap ketiak daun akan terakumulasi sejumlah zat hasil fotosintesis yang akan merangsang terbentuknya tunas-tunas daun. Dari sidik ragam (Anova) menunjukkan aplikasi takaran biochar sekam padi dan kompos kotoran ayam tidak memberikan efek yang signifikan pada berat bunga tanaman per petak.

Hasil uji lanjut menunjukkan tidak ada pengaruh nyata pada setiap perlakuan tetapi data pada tabel menunjukkan bahwa pemberian takaran kompos kotoran ayam $5 \mathrm{t} /$ ha bunga tanaman per petak paling berat, yakni sebesar 3,35 t/ha. Dengan berat bunga pertanaman 25,96 g. Tingginya berat bunga tidak terlepas dari besaran diameter bunga. Semakin besar diameter bunga semakin besar pula berat yang dihasilkan. Diameter bunga paling besar dihasilkan pada takaran kompos kotoran ayam 5 t/ha dengan diameter sebesar $8,25 \mathrm{~cm}$. Proses pertumbuhan dan perkembangan tanaman kubis bunga ditentukan oleh kandungan air tanaman kubis bunga yang diserap dari dalam tanah. Hal ini berhubungan dengan ketersediaan hara dalam tanah. Kompos kotoran ayam memiliki cukup hara untuk menyokong pertumbuhan dan perkembangan tanaman serta memiliki kemampuan menyimpan air yang cukup sehingga pertumbuhan tanaman menjadi lebih baik seiring dengan penambahan jumlah kompos kedalam tanah. Biochar juga menyumbangkan hara bagi tanaman walau pun dalam jumlah sedikit, tetapi biochar termasuk pembenah tanah yang mampu bertahan didalam tanah, menyerap dan menyimpan hara dan air serta dilepaskan sesuai dengan kebutuhan tanaman.

\section{Simpulan}

Berdasarkan hasil penelitian diatas maka dapat disimpulkan beberapa hal yaitu tidak terjadi interaksi antar perlakuan pada semua parameter pengamatan, baik pada parameter pertumbuhan maupun pada parameter hasil. Perlakuan biochar sekam padi menunjukkan tidak berbeda nyata pada semua parameter pengamatan, tetapi takaran 5 t/ha menghasilkan pertumbuhan dan hasil maksimum. Perlakuan kompos kotoran ayam 5 t/ha menghasilkan pertumbuhan dan hasil maksimum yang berbeda nyata dengan kontrol pada semua parameter pengamatan kecuali pada berat bunga per tanaman.

\section{Pustaka}

Ardi D.S., \& R.D.M. Simanungkalit., 2006., Pupuk Organik Dan Pupuk Hayati Organic Fertilizer And Biofertilizer., Balai Besar Litbang Sumberdaya Lahan Pertanian Badan Penelitian dan Pengembangan Pertanian

BPS Indonesia. 2011. Produksi Sayuran di Indonesia.

BPS Indonesia. 2015. Produksi Sayuran di Indonesia.

Gani, A. 2009.Potensi Arang Hayati Biochar sebagai Komponen Teknologi Perbaikan Produktivitas Lahan Pertanian. Iptek Tanaman Pangan $4(1): 33-48$.

Gomez, K. A. dan Gomez, A. A. 1995. Prosedur Statistik Untuk Penelitian Pertanian. Edisike 2. UI Press: Jakarta.

Kloss,S.,F.Zehetner,B. Wimmer,J. Buecker,F. Rempt,andG.Soja. 2014. Biochar application to temperate soils: Effects on soil fertility and crop grow thunder green house conditions. J. Plant Nutr. Soil Sci. :177,3-15. Nazemi.

Lehmann Johannes., 2007., A handful of carbon., A Natureresearch journal.,https://doi.org/10.1038/447143a.,

Rubatzaky V.E. dan M. Yamauchi. 1998. Sayuran Dunia Prinsip, Produksi dan Gizi Jilid II. ITB. Bandung. 292 hal.

Simalango, E. 2009. Keuntungan Menggunakan Pupuk Organik. http://eriantosimalango.wordpress. /2009/05/14/keuntungan menggunakan-pupuk-organik/[15/10/2011].

Sun, F. dan S. Lu. 2014. Biochars improve aggregate stability, water retention, and pore space properties of clayey soil. J. Plant Nutr. Soil Sci. $177,26-33$

Sunarsih Endang Sri, Lukman Hakim, Sugiyanto, Sumantri., Senyawa Aktif Sayuran Cruciferae dan Perubahan Kadar Kolesterol serta Vitamin C pada Tikus Hiperkholesterolemia., Media Medika Indonesiana., Volume 45, Nomor 3:151-15

Widowati. L. R., Sri Widati, U. Jaenudin, \&W. Hartatik. 2004. Pengaruh pupuk kompos organik yang diperkaya dengan bahan mineral dan pupuk hayati terhadap sifat-sifat tanah, serapan hara dan produksi sayuran organik. Laporan Proyek Penelitian Program Pengembangan Agribisnis Balai Penelitian Tanah. 